\title{
MEMPREDIKSI JUMLAH PENERIMAAN DAN PERMINTAAN DARAH DI PALANG MERAH INDONESIA (PMI) KITA MEDAN DENGAN MENGGUNAKAN METODE ID3 (STUDI KASUS: PMI KOTA MEDAN)
}

\author{
Annisa Corry Nauli Sirait ${ }^{1}$, Efori Buulolo², Hukendik Hutabarat ${ }^{3}$ \\ ${ }^{1,2,3}$ Program Studi Teknologi Informatika STMIK Budi Darma,Medan, Indonesia \\ Email: ${ }^{1}$ acorrynauli@gmail.com, ${ }^{2}$ buuloloefori21@gmail.com
}

\begin{abstract}
Abstrak
Palang Merah Indonesia (PMI) merupakan sebuah organisasi perhimpunan nasional di Indonesia yang bergerak dalam bidang sosial kemanusiaan. Pada bulan tertentu kebutuhan darah meningkat drastis, hal ini menyebabkan ketersedian darah di Palang Merah Indonesia Kota Medan semakin menipis. Selain kekurangan darah, kelebihan persediaan darah juga sering terjadi di Palang Merah Indonesia. Untuk mengatasi permasalahan diatas maka pihak Palang Merah Indonesia (PMI) Kota Medan melakukan penyediaan stok darah agar pada saat kebutuhan tinggi mereka dapat menyetarakan stok dan jika kebutuhan darah rendah mereka dapat menstabilkan darah agar darah tersebut tidak terbuang. Mengatasi permasalahan tersebut, maka perlu dibangun aplikasi Implementasi Jumlah Penerimaan dan Permintaan Darah di Palang Merah Kota Medan dengan menggunakan metode ID3 (Iterative Dichoimoiser 3) sehingga membantu dalam proses penyetaraan darah agar lebih akurat serta keputusan yang ditetapkan hasilnya valid dan memuaskan.
\end{abstract}

Kata Kunci: Data Mining, Penerimaan dan Permintaan Darah, Id3 (Iterative Dichoiomiser)

\begin{abstract}
The Indonesian Red Cross (PMI) is a national association organization in Indonesia engaged in the field of social humanity. In certain months the blood demand has increased dramatically, this causes the availability of blood in the Indonesian Red Cross Medan City increasingly thinning. In addition to lack of blood, excess blood supply is also common in the Indonesian Red Cross. To overcome the above problems, the Indonesian Red Cross (PMI) of Medan City is supplying blood stock so that when the needs are high they can balance the stock and if their blood needs are low they can stabilize the blood so that the blood is not wasted. To overcome these problems, it is necessary to build an application for the Implementation of the Amount of Blood Receipts and Demand in the Medan Red Cross by using the ID3 (Iterative Dichoimoiser 3) method so that it helps in the process of equalizing blood to make it more accurate and the decisions determined to be valid and satisfactory.
\end{abstract}

Keywords: Data Mining, Blood Acceptance and Demand, Id3 (Iterative Dichoiomiser)

\section{PENDahuluan}

Palang Merah Indonesia (PMI) merupakan sebuah organisasi perhimpunan nasional di Indonesia yang bergerak dalam bidang sosial kemanusiaan. PMI selalu mempunyai tujuh prinsip dasar Gerakan Internasional Palang Merah dan Bulan sabit merah yaitu kemanusiaan, kesamaan, kesukarelaan, kemandirian, kesatuan, kenetralan, dan kesemestaan[1]. Rancangan tersebut mendapat dukungan luas terutama dari kalangan terpelajar Indonesia, dan diajukan ke dalam Sidang Konferensi Narkai pada 1940, akan tetapi ditolak mentah-mentah.

Pelayanan darah adalah upaya pelayanan kesehatan yang memanfaatkan darah manusia sebagai bahan dasar dengan tujuan kemanusiaan dan tidak untuk tujuan komersial. PMI terus mengampanyekan donor darah sebagai bagian dari gaya hidup. Setiap tahunnya, PMI menargetkan hingga 4,5 juta kantong darah sesuai dengan kebutuhan darah nasional, disesuaikan dengan standar Lembaga Kesehatan Nasional (WHO) yaitu 2\% dari jumlah penduduk setiap harinya Seiring dengan keadaan cuaca di Indonesia terjangkit berbagai macam penyakit. Pasien penderita penyakit tertentu biasanya akan kehilangan banyak darah merah ataupun darah putih didalam tubuhnya. Untuk memulihkan kondisi tubuh penderita maka diperlukan upaya transfusi darah sehingga kadar darah merah dan darah putih didalam tubuh normal kembali. Persediaan darah untuk seluruh golongan darah, padahal permintaan stok darah selalu meningkat. Pada bulan tertentu kebutuhan darah meningkat drastis, hal ini menyebabkan ketersedian darah di Palang Merah Indonesia Kota Medan semakin menipis. Selain kekurangan darah, kelebihan persediaan darah juga sering terjadi di Palang Merah Indonesia. Dan ketika stok persediaan kelebihan, kualitas darah tersebut juga semakin tidak baik dan kantong darah harus dimusnahkan karena kadaluarsa. Hal tersebut Palang Merah Indonesia (PMI) diharapkan untuk dapat mengontrol jumlah penerimaan dan permintaan darah agar tidak terjadi kekurangan dan kelebihan stok darah.

Melalui data yang diperoleh dari PMI (Palang Merah Indonesia) dapat dilakukan proses data mining untuk menentukan jumlah penerimaan dan permintaan darah dan bagaimana cara mengatasi kekurangan serta kelebihan darah pada PMI (Palang Merah Indonesia). Metode yang dipakai dalam data mining ini adalah metode ID3 (Iterative Dichotomiser 3).

ID3 adalah algoritma Decision tree learning (algoritma pembelajarn pohon keputusan) yang menggunakan strategi pencarian hiil-climbing, yaitu dimulai dari pohon kosong, kemudian secara progresif berusaha menemukan sebuah pohon keputusan yang mengklasifikasikan sampel-sampel data secara akurat tanpa kesalahan. Pertumbuhan cabang-cabang pohon keputusan pada algoritma ID3 dilakukan sampai pohon tersebut mampu mengklasifikasikan sampel data secara akurat dengan tingkat kebenaran 100\% sesuai dengan data latih.

\section{TEORITIS}




\subsection{Data Mining}

Data mining adalah proses yang mempekerjakan satu atau lebih teknik pembelajaran komputer (machine learning) untuk menganalisa dan mengekstrak pengetahuan secara otomatis. Data mining berisi pencarian trend atau pola yang diinginkan dalam database besar untuk membantu pengambilan keputusan diwaktu yang akan datang. Pola-pola ini dikenali oleh perangkat tertentu yang dapat memberikan suatu analisa data yang berguna dan berwawasan yang kemudian dapat dipelajari dengan lebih teliti, yang mungkin saja menggunakan perangkat pendukung keputusan lainnya[3][4][5][6].

\subsection{Algoritma ID3}

Algoritma ID3 atau Interative Dichotomiser 3 (ID3) merupakan sebuah metode yang digunakan untuk membangkitkan pohon keputusan. Algoritma pada metode ini menggunakan konsep entropy informasi. Pemilihan atribut dengan menggunakan Information Gain.

Pemilihan atribut pada ID3 dilakukan dengan properti statistik, yang disebut dengan information gain. Gain mengukur seberapa baik suatu atribut memisahkan training example ke dalam kelas target. Atribut dengan informasi tertinggi akan dipilih. Dengan tujuan untuk mendefinisikan gain, pertama-tama digunakanlah ide dari teori informasi yang disebut entrophy. Entropy mengukur jumlah dari informasi yang ada pada atribut dengan rumus:

\section{Entropy $(S)=-p . \log 2 p+-P . \log 2 p$}

Keterangan:

$\mathrm{S} \quad$ =ruang (data) sample yang digunakan untuk training.

$\mathrm{P} \quad$ =jumlah yang bersolusi positif (mendukung) pada data sample untuk kriteria tertentu.

$\mathrm{P}_{-} \quad$ =jumlah yang bersolusi negative (tidak mendukung) pada data sample untuk kriteria tertentu. Dari rumus entropy diatas dapat disimpulkan bahwa definisi entropy $(S)$ adalah jumlah bit yang diperkirakan dibutuhkan untuk dapat mengekstrak suatu kelas (+ atau -) dari sejumlah data acak pada suatu ruang sample $S$.

Entropy bisa dikatakan sebagai kebutuhan bit untuk menyatakan suatu kelas. Semakin kecil entropy maka semakin baik digunakan dalam mengekstrasi suatu kelas. Pada algoritma ID3 pengurangan entropy disebut dengan informasi gain. Pembagian sample $S$ terhadap atribut A dapat dihitung informasi gain dengan rumus:

\section{$\operatorname{Gain}(\mathrm{S}, \mathrm{A})=\operatorname{Entropy}(\mathrm{S})-\sum \mathrm{vE} \operatorname{Value}(\boldsymbol{A}) \frac{|\mathrm{|sv}|}{|\mathrm{S}|} \operatorname{Entropy}(\mathrm{Sv})$}

Keterangan:

A

$\mathrm{V} \quad \quad=$ Suatu nilai yang mungkin untuk atribut $\mathrm{A}$

Value (A) =Himpunan yang mungkin untuk atribut $\mathrm{A}$

$|\mathrm{Sv}| \quad=$ Jumlah sample untuk nilai $\mathrm{v}$

|S| =Jumlah seluruh sampel data

Entropy $(|\mathrm{Sv}|)=$ Entropy untuk sampel-sampel yang memiliki nilai $\mathrm{v}$

Pilih atribut yang memiliki nilai information gain akan terus dilaksanakan sampai semua data telah masuk dalam kelas yang sama. Atribut yang telah dipilih tidak diikutkan lagi dalam perhitungan nilai informasi gain.

\section{ANALISA DAN PEMBAHASAN}

\subsection{Analisa Masalah}

PalangMerah Indonesia (PMI) adalah salah satu pengelola dan pelaksanaan penyediaan darah di Indonesia. Dalam sistem penerimaan dan permintaan darah PMI mempunyai berbagai macam prosedur yaitu: dalam proses penerimaan darah mereka melakukan berbagai macam jenis pengecekan mulai dari pendaftaran sicalon pendonor,seleksi donor,administrasi dan pengambilan darah. Dan dalam proses permintaan PMI mempunyai syarat tertentu,dan siapapun dapat mengambil darah ke PMI dengan membawa surat pengantar dari dokter ataupun rumah sakit. Dan untuk kualitas darah hanya dapat bertahan dalam sebulan jika dalam sebulan darah tidak terpakai maka darah akan dimusnahkan. Untuk mengantisipasi hal tersebut PMI selalu berusaha menyetarakan proses penerimaan dan permintaan darah tersebut. PalangMerah Indonesia (PMI) belum ada bantuan murni dari pemerintah dan memang masih PMI yang menanggung dan murni dari bantuan masyarakat dan sumbangan terikat lainnya. Dengan menggunakan algoritma Interative Dichoiomiser 3 (ID3) dapat membantu PMI dalam pengklasifiksian data permintaan dan penerimaan darah. Proses mencari data yang diperoleh dari hasil studi lapangan seperti wawancara dan pengamatan yang dilakukan dan hasilnya akan membentuk pohon keputusan. Penerapan Algoritma Interative Dichoiomiser 3 (ID3). Algoritma ID3 atau Interative Dichoimoiser 3 (ID3) merupakan sebuah merode yang digunakan untuk membuat pohon keputusan yang telah dikembangkan oleh J. Ross Quinlan.

\subsection{Pre-Procesing Data}

Algoritma ID3 merupakan algoritma yang diguinakan untuk membentuk pohon keputusan. Pemrosesan data mining menggunakan algoritma ID3 degngan melakukan pengumpulan data dan mengklasifikasikan data menggunakan representasi struktur pohon keputusan dimana setiap node mempresentasikan nilai dari atribut dan daun 
mempresentasikan node. Data yang dimiliki akan disusun menjadi sebuah tabel dan jumlah responden sebelum dilakukan perhitungan untuk mencari nilai entropy dan gain. Adapun tahap yang digunakan pada algoritma ID3 adalah:

1. Pilih atribut sebagai akar.

2. Buat cabang untuk tiap-tiap nilai.

3. Bagi kasus dalam cabang.

4. Ulangi proses untuk setiap cabang sampai semua kasus pada cabang memiliki kelas yang sama.

\subsection{Analisa Data}

Untuk pemilihan atribut sebagai akar, didasarkan pada nilai gain tertinggi dari atribut-atribut yang ada dengan menggunakan dua persamaan maka akan didapatkan entropy dan gain yang digunakan sebagai akar dalam membuat pohon keputusan. Untuk menggunakan dua persamaan Nilai Entropy berdasarkan penilaian keseluruhan data berdasarkan tabel Data Decision Komponen Darah.

Tabel 1. Data Klasifikasi Komponen Darah PMI Januari-April 2019

\begin{tabular}{|c|c|c|c|c|c|}
\hline No & Jenis Darah & Produksi & Permintaan & Pemakaian & Hasil \\
\hline 1. & Fresh Frozen Plasma & Banyak & Banyak & Banyak & Rendah \\
\hline 2. & Packed Red cell & Banyak & Sedikit & Banyak & Rendah \\
\hline 3. & Whole Blood & Banyak & Sedikit & Sedikit & Tinggi \\
\hline 4. & Trombocyte Consentrat (Biasa) & Sedikit & Sedikit & Sedikit & Rendah \\
\hline 5. & Cryo-precipitate/AHF & Banyak & Sedikit & Sedikit & Rendah \\
\hline 6. & Whashed Erythrocytes & Banyak & Sedikit & Sedikit & Tinggi \\
\hline 7. & TrombocyteConsentrat (Apheresis) & Banyak & Sedikit & Sedikit & Tinggi \\
\hline 8. & Fresh Frozen Plasma & Banyak & Banyak & Sedikit & Rendah \\
\hline 9. & Packed Red cell & Banyak & Sedikit & Sedikit & Tinggi \\
\hline 10. & Whole Blood & Banyak & Sedikit & Sedikit & Tinggi \\
\hline 11. & Trombocyte Consentrat (Biasa) & Sedikit & Sedikit & Sedikit & Rendah \\
\hline 12. & Cryo-precipitate/AHF & Sedikit & Sedikit & Sedikit & Rendah \\
\hline 13. & Whashed Erythrocytes & Banyak & Sedikit & Sedikit & Rendah \\
\hline 14. & Trombocyte Consentrat (Apheresis) & Banyak & Sedikit & Sedikit & Tinggi \\
\hline 15. & Fresh Frozen Plasma & Banyak & Sedikit & Sedikit & Rendah \\
\hline 16. & Packed Red cell & Banyak & Sedikit & Sedikit & Rendah \\
\hline 17. & Whole Blood & Banyak & Sedikit & Sedikit & Tinggi \\
\hline 18. & Trombocyte Consentrat (Biasa) & Sedikit & Sedikit & Sedikit & Tinggi \\
\hline 19. & Cryo-precipitate/AHF & Banyak & Sedikit & Sedikit & Rendah \\
\hline 20. & Whashed Erythrocytes & Sedikit & Sedikit & Sedikit & Rendah \\
\hline 21. & Trombocyte Consentrat (Apheresis) & Banyak & Sedikit & Sedikit & Rendah \\
\hline 22. & Fresh Frozen Plasma & Banyak & Sedikit & Sedikit & Tinggi \\
\hline 23. & Packed Red cell & Banyak & Sedikit & Sedikit & Rendah \\
\hline 24. & Whole Blood & Sedikit & Sedikit & Sedikit & Rendah \\
\hline 25. & Trombocyte Consentrat (Biasa) & Sedikit & Sedikit & Sedikit & Rendah \\
\hline 26. & Cryo-precipitate/AHF & Banyak & Sedikit & Sedikit & Tinggi \\
\hline 27. & Whashed Erythrocytes & Banyak & Sedikit & Sedikit & Tinggi \\
\hline 28. & Trombocyte Consentrat (Apheresis) & Sedikit & Sedikit & Sedikit & Rendah \\
\hline
\end{tabular}

Setelah itu hitung nilai Entropy dari atribut Permintaan = Sedikit yang memiliki jumlah kasus "8" seperti terlihat pada kasus dibawah ini

1. Nilai Entropy

Berikut ini adalah tabel penyelesaiannya.

Tabel 2. Sampel Yang Diuji Ulang

\begin{tabular}{ccccc}
\hline Kriteria & Atribut & Jumlah kasus & Rendah & Tinggi \\
\hline Permintaan & Sedikit & 8 & 1 & 7 \\
\hline
\end{tabular}

Setelah itu, hitung nilai entropy dari atribut Produksi $=$ Sedikit seperti yang terlihat pada tabel dibawah ini.

Tabel 3. Atribut Produksi

\begin{tabular}{clcccc}
\hline No & Jenis Darah & Produksi & Permintaan & Pemakaian & Hasil \\
\hline 1. & Trombocyte Consentrat (Biasa) & Sedikit & Sedikit & Sedikit & Rendah
\end{tabular}


2. Trombocyte Consentrat (Biasa)

3. Cryo-precipitate/AHF

4. Trombocyte Consentrat (Biasa)

5. Whashed Erythrocytes

6. Whole Blood

7. Trombocyte Consentrat (Biasa)

8. Trombocyte Consentrat (Apheresis)

$\begin{array}{ll}\text { Sedikit } & \text { Sedikit } \\ \text { Sedikit } & \text { Sedikit } \\ \text { Sedikit } & \text { Sedikit } \\ \text { Sedikit } & \text { Sedikit } \\ \text { Sedikit } & \text { Sedikit } \\ \text { Sedikit } & \text { Sedikit } \\ \text { Sedikit } & \text { Sedikit }\end{array}$

Sedikit

Sedikit

Rendah

Sedikit

Sedikit

Sedikit

Sedikit

Sedikit

Rendah

Tinggi

Rendah

Rendah

Rendah

Rendah

Langkah selanjutnya menghitung nilainya, berikut ini adalah rekapitulasi nilai entropy dan Gainnya.

Tabel 4. Atribut Komponen Darah

\begin{tabular}{|c|c|c|c|c|c|c|c|}
\hline Node & & Keterangan & Jlh Kasus (s) & Tinggi & Rendah & Entropy & Gain \\
\hline \multirow[t]{7}{*}{1} & Produksi $=$ Sedikit & & 8 & 1 & 7 & 0.5435644432 & \\
\hline & Permintaan & & & & & & 0 \\
\hline & & Banyak & 0 & 0 & 0 & 0 & \\
\hline & & Sedikit & 8 & 1 & 7 & 0.5435644432 & \\
\hline & Pemakaian & & & & & & 0 \\
\hline & & Banyak & 0 & 0 & 0 & 0 & \\
\hline & & Sedikit & 8 & 1 & 7 & 0.5435644432 & \\
\hline
\end{tabular}

Berdasarkan tabel diatas terlihat bahwasanya Attribut Pemakaian memiliki nilai Gain tertinggi, maka untuk Root selanjutnya pada phon keputusannya dapat terlihat pada gambar pohon (Tree) berikut ini:

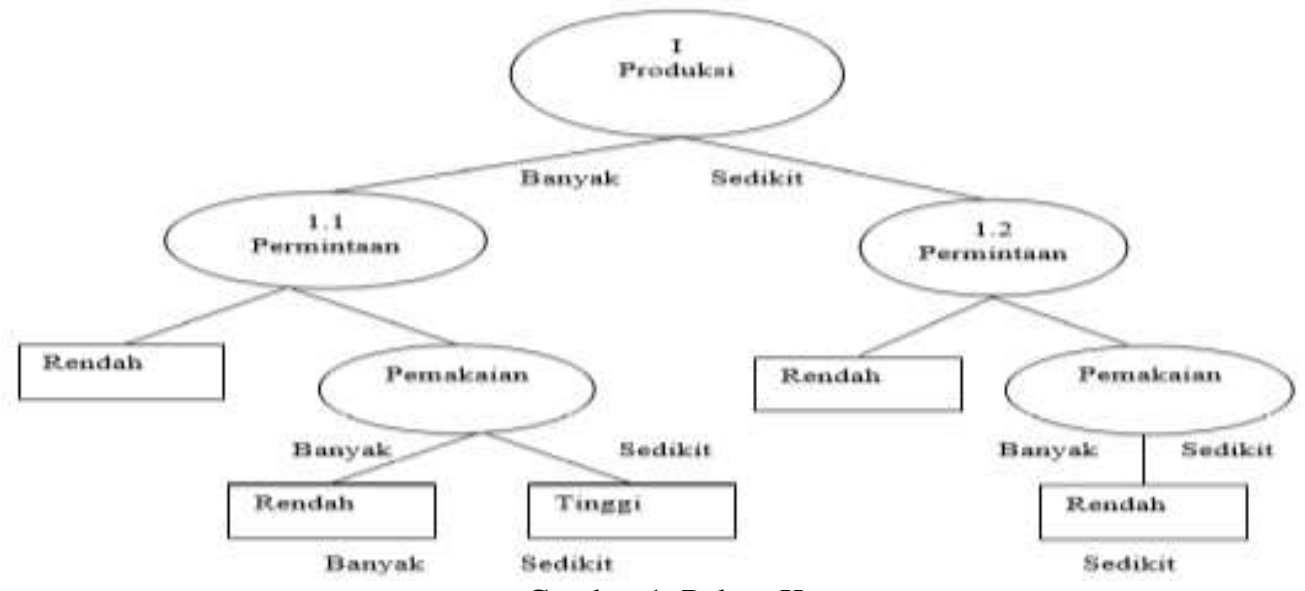

Gambar 1. Pohon Keputusan

Berdasarkan dari pohon keputusan yang terbentuk seperti diatas maka dapat dihasilkan rule sebagai berikut :

1. Jika Produksi $=$ Banyak dan Permintaan $=$ Banyak maka hasil $=$ Rendah

2. Jika Produksi $=$ Banyak dan Permintaan $=$ Sedikit dan Pemakain $=$ Banyak maka hasil $=$ Rendah

3. Jika Produksi $=$ Banyak dan Permintaan $=$ Sedikit dan Pemakain $=$ Sedikit maka hasil $=$ Tinggi

4. Jika Produksi $=$ Sedikit dan Permintaan $=$ Banyak maka hasil $=$ Rendah

5. Jika Produksi $=$ Sedikit dan Permintaan $=$ Sedikit dan Pemakaian $=$ Sedikit maka hasil $=$ Rendah

\section{IMPLEMENTASI}

Implementasi merupakan suatu tindakan untuk mewujudkan terlaksananya rencana dalam mencapai tujuan tertentu. Implementasi sistem meliputi spesifikasi kebutuhan perangkat keras (hardware), perangkat lunak (software) dan hasil pengujian. Perangkat keras merupakan salah satu komponen dari sebuah komputer yang sifat alatnya bias dilihat dan dapat disentuh oleh manusia secara langsung atau berbentuk nyata, yang berfungsi untuk mendukung proses komputerisasi. Perangkat lunak merupakan program-program komputer yang berguna untuk menjalankan suatu pekerjaan sesuai dengan dikehendaki. Program tersebut ditulis dengan bahasa khusus yang dimengerti oleh komputer.

\subsection{Data Yang Diolah}

Data diperoleh dari hasil suatu pengamatan dalam bentuk angka dengan fakta dan disajikan sebagai bahan dasar untuk mendapatkan suatu informasi yang bermanfaat setelah data tersebut diolah. Data yang akan digunakan dalam pengolahan merupakan data praproses dari data data jumlah penerimaan dan permintaan darah yang telah dilakukan dan dibuat dalam Microsoft Excel dengan atribut yang sudah ditentukan. 


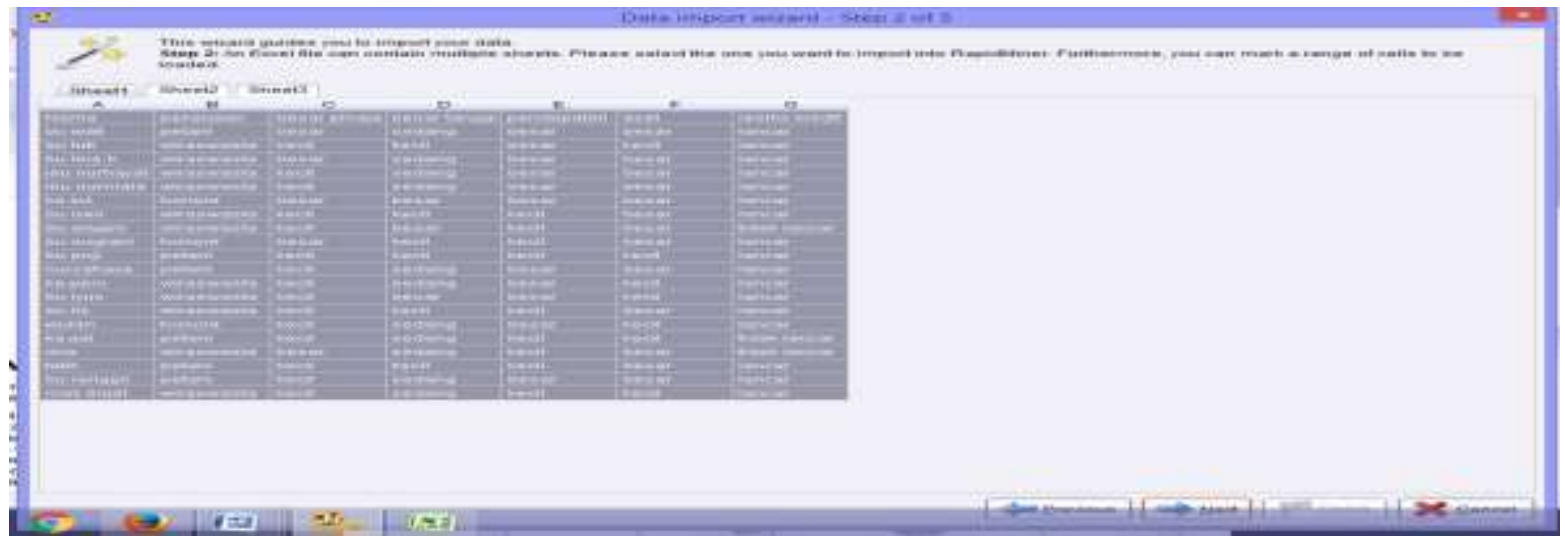

Gambar 2. Tampilan data Praproses dalam Microsoft Excel

Pada gambar 2 adalah menentukan minimal gain yang berfungsi untuk menghasilkann simpul pohon keputusan, dan minimal leaf size untuk menghasilkan pohon sebanyak leaf size yang di input pada gambar $2 .$.

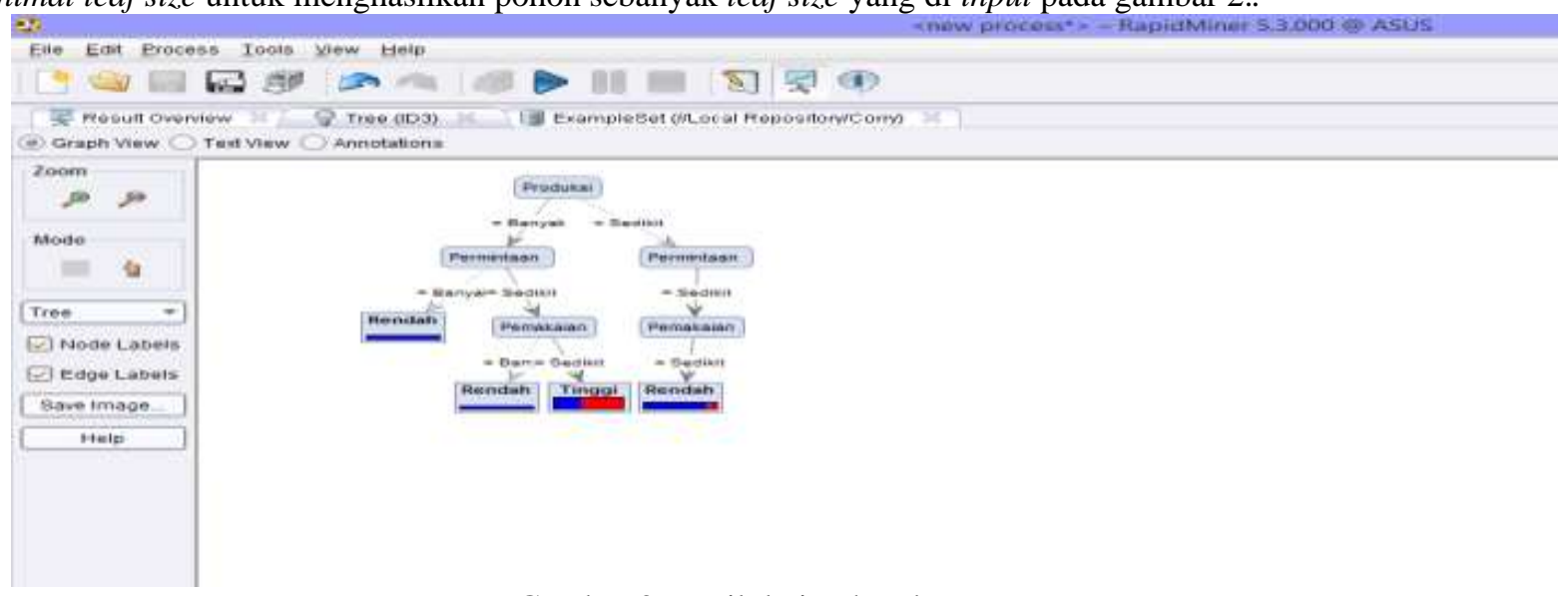

\section{KESIMPULAN}

Gambar 3. Hasil dari pohon keputusan

Berdasarkan uraian pada bab-bab sebelumnya, maka penulis mengambil keputusan sebagai berikut.

1. Metode ID3 dengan data-data sebelumnya dapat memprediksi data jumlah penerimaan dan permintaan darah bulan Januari-April 2019.

2. Adapun hasil dari prediksi data jumlah penerimaan dan permintaan darah bulan Januari- April 2019 dengan metode ID3 yang memperoleh hasil rule.

3. Hasil prediksi dari data jumlah penerimaan dan permintaan darah dalam memprediksi data jumlah penerimaan dan permintaan darah bulan Januari-April 2019.

\section{REFERENCES}

[1] Https://id.wikipedia.org/wiki/Palang_Merah_Indonesia, "PALANG MERAH INDONESIA.".

[2] C. F. Cadwell Marthin Rumagit, "PENERAPAN METODE ID3 TERHADAP PERANCANGAN SISTEM PENENTUAN PENERIMAAN BANTUAN SOSIAL PEMUGARAN RTLH KOTA SALATIGA,” vol. 2, no. 2476-8812, p. 115, 2016.

[3] Kusrini dan Emha Taufiq Luthfi, Algoritma Data Mining. Yogyakarta: CV. Andi Offset, 2009.

[4] Beta Noranita dan Nurdin Bahtiar, Data Mining. 2010.

[5] E. T. L. Kusrini, Algoritma Data Mining. Yogyakarta: CV.Andi Offset, 2009.

[6] F. S. dan D. Juju, Data Mining Meramalkan Bisnis Perusahaan. 2013.

[7] W. org/wiki/Donor_dara. Https://id., "Penerimaan." .

[8] W. org/wiki/Permintaa. Https://id., "Permintaan." .

[9] Https://elib.unikom.ac.id/files/693/jbptunikompp-gdl-widitasiti-34632-9-unikom_w-i.pdf, "Darah." .

[10] Https://id.wikipedia.org/wiki/Donor_darah, "Penerimaan Dan Permintaan Darah.”.

[11] Edhy Sutanta, Pengantar Teknologi Informasi. Yogyakarta, 2005.

[12] D. Didayatulah, Startup Screen Tanagra. .

[13] https://www.kelasexcel.web.id/2014/06/pengenalan-sejarah-dan-pengertian-microsoft-excel.html, "Microsoft Excel 2003." 